\title{
The intimate borders of epidemiological nationalism
}

\section{Bryonny Goodwin-Hawkins}

\begin{abstract}
Aвstract: Amidst the COVID-19 crisis, nation-states closed borders. Borders divide - and intimate difference. In this article, I trace an emergent epidemiological nationalism which intimates a contagious other, taking 'the' border as my (unstable) object. While post-war and post-wall European projects celebrate dismantling borders, bordering continually becomes by saturating space with territoriality. Illustrating epidemiological nationalism's intimately located here and there, I turn an ethnographic gaze to Wales: a nation yet not a state, with a border that cannot be closed. Through the socio-spatial saturate of the Welsh border's enduring (non)existence run frictive, entangled intimacies. Meshing border studies with Lauren Berlant's theorisation of intimacies, I show epidemiology's conscription in imaginatively inscribing a safely state-like Welsh nation.
\end{abstract}

KeYwords: borders, Britain, COVID-19, identity, nationalism, Wales

In May 2020, weeks into COVID-19 lockdown, two police commissioners wrote to the Welsh Government requesting extraordinary powers. 'The movement of people from more densely populated areas with higher infection rates to more rural communities is creating un-needed tensions,' wrote one, as the restricted realities of cramped city life led those who could to decamp to rural holiday homes. For weeks, the Welsh public sphere had run taut with rumour and concern: city-dwellers were ignoring fines, unfairly claiming relief funds, travelling at night, sending suitcases ahead to avoid suspicion. COVID-19 cases were indeed spreading and rural health facilities few. Some rural residents responded with spraycans and placards: 'GO HOME' emblazoned roads into villages and fences on farms. Fears bubbled; risks, too, were real.

For the police commissioners, authoritative action would protect Welsh communities. But Wales' First Minister was quick to quash requests. Speaking on $\mathrm{BBC}$ radio, he addressed the commissioners' demands by observing how far the pandemic had shifted national discourse: 'It would have been absolutely astonishing ten weeks ago to be talking about evicting people from their own homes.'
Police powers to evict second home owners from rural Wales were never granted. That they were imagined and articulated, however, speaks indeed to a discourse in which epidemiology enforced who belonged where: go home. In a crisis made amid a mobile world, sedentarism promised seemingly simple solutions: stay home. Andrew Dawson and Simone Dennis (2020) have recently described the rural dis-location of danger to urban others as 'disaster nativism'. Swelled by fear and disruption, disaster nativism fosters the shared sentiment of belonging somewhere small and - if only kept 'ours' - safe. Yet, while imagined evictions clearly depended on the twitching curtains of informing neighbours, Welsh shared sentiment stretched beyond parochial rural bounds to the space of a small nation. Disaster nativism became epidemiological nationalism.

In this essay, I trace epidemiology's conscription in nationalist inscription. I invoke 'nationalism' without the presumption that the term always already entails a regressive politics. (Plaid Cymru - the dominant Welsh nationalist party - is social democratic, centreleft and pro-EU.) There is nothing pre-given about particular scales (Swyngedouw 1997), whether nation, Gemeinschaft or globe. Equally, there is nothing 
natural about nations, nor inherent about their borders. My interest, then, is to understand how epidemiology could construct and legitimate the nation as bordering threat and promising safety.

I take as my (unstable) object not the nation but 'the' border. After 1989, 'breathless proclamations' from across the political spectrum imagined a borderless 'smooth new world map of globalisation' (Saxer \& Andersson 2019: 14). Borders, nevertheless, 'have not withered away in the face of the ... onslaught' (Wilson \& Donnan 2012: 6). Borders still bring territories into existence; still distinguish here from there (Green 2013), us from them (Barth 1969), who can cross from who cannot (Yuval-Davis et al. 2019). Borders divide by intimating difference and, as I suggest here, by delimiting epidemiological terrain and viral transgression.

In the pandemic's early weeks, growing awareness that viral transmissions rode global mobility flows led many nation-states to close borders. Restricting mobility to halt viral spread made sound epidemiological sense. Yet restrictions inevitably drew upon pre-existing borders between people and places borders that were socially, politically and historica lly inscribed before becoming epidemiologically legible. Permeating cells, viral bodies had no ken for the geographies of their replication. Human bodies, however, were controlled and counted by territory. As national governments and synecdoche leaders took front stage in the naming of crisis (Roitman 2013), wartime metaphors evoked both 'homefront' patriotisms and lingering divisions, while media reportage ranked nations by death and diagnosis. By making the nation count, epidemiology made the nation matter - as a normative scale for viral control and citizen-state care (Trnka 2020).

Simultaneously, being 'all in this together' invoked what Lauren Berlant has termed the national 'intimate public', an 'affective scene of identification among strangers that promises a certain experience of belonging and provides a complex of consolation, confirmation, discipline and discussion' (2008: viii). Berlant's intimate publics manifest in cultural consumption and political juxtaposition; but an intimate public might also become as the cellular intimacies of viral transmission transform into the shared sentiment of bordered belonging.

If epidemiological nationalism arose in the slippage between viral containment and territorial container (Taylor 1994), whose nation mattered? Enfolded in the UK model of devolved political union, Wales is a nation but not a state, with a national government but no national citizens, and a land border that cannot be lawfully closed. Crossed by 244 roads and nine railways the Welsh border has had little concrete presence since England and Wales were incorporated in the sixteenth century. Yet the bordering logics epidemiology enabled were soon made imaginatively present in Wales. After reports emerged of high visitor numbers at scenic spots, an online anti-tourism campaign re-worked vintage holiday advertising with the message: don't visit Wales. Early into lockdown, social media circulated stories of roadblocks and checkpoints; one (later admitted fake) claiming that Welsh police were fining motorists with English plates. The stories spoke both to new realities of restricted mobility and discourses of whose mobility really was dangerous. The 'densely populated areas with higher infection rates' that the police commissioners warned of were not Welsh cities, nor generic elsewheres - but specifically England. Viral Englishness was named by (some) Welsh politicians; evoked among the intimate public who knew 'second homes' recalled the infamous 1980s Meibion Glyndŵr anti-English arson campaign; and rehearsed in the pointed monolingualism of 'Go Home' graffiti (a message never aimed at Welsh speakers, ${ }^{1}$ and contrasted by bilingual mutual aid fliers). For weeks, the shared sentiment of dis-located dis-ease hung in a bedsheet banner at the threshold to my own, small Welsh town: 'Your Holiday, Our Lives'.

Real or rumoured, English travellers to Wales crossed a border through which safety and nation increasingly intertwined. The narrative of cross-border contagion took statistical shape when early data from King's College London's COVID-19 Symptom Study app suggested that Welsh counties popular with (English) second home owners were becoming viral hotspots. Gwynedd councillors additionally took to the media, irate that second home owners might claim $£ 15-18$ million in business rates relief through a taxation loophole. I want to avoid spinning a statistical story of my own here. The melange of testing regimes, reporting dates, self-reporting, under-reporting, contact tracing and death classification offers little objective clarity. There are English and Welsh identities, not legal nationalities, and the 24,000 tax-registered second homes in Wales are neither classified nor classifiable by national ownership. But insofar as statistics storied the where of death and diagnosis, a view of the nation emerged in the daily case numbers read out in the Welsh Parliament (Senedd) and a national $\mathrm{R}$ rate became talismanic of a national response, in growing distinction to UK measures. 
'Why remain passive in the face of other peoples' borders when you can obtain advantage by becoming a pro-active borderer?' Chris Rumford (2007: 337) asked, long before COVID-19. If the Welsh border's physical (im)possibility became imperative for an intimate public, the Welsh Government's own response manifested less lineal 'shifts in the ground underneath everyone's feet' (Green 2013: 349). I have written elsewhere of the 'slow saturation of [Welsh] space with territoriality' (Goodwin-Hawkins \& Dafydd Jones 2019: 323) since devolution in 1999, in part through a UK governance model that enables policy divergence. Indeed, the Welsh border's enduring (non)existence does not manifest materially along the border, but in socio-spatial intimation and the mundane effects of devolved policies (GoodwinHawkins \& Dafydd Jones 2019). Devolution did not give Wales the power to physically close the border, but devolution did give the Welsh Government control over healthcare and crisis management. Those powers in turn enabled the epidemiological inscription of a safely state-like Wales. When the UK Government eased lockdown restrictions in early May, the Welsh Government refused to follow suit. In a spatial surrealism, it became legal in the UK to drive to a beach, for example, but simultaneously illegal to do so in Wales. The UK Government was backed into effectively speaking only for England, and major media outlets were forced to specify their coverage by nation, amidst complaints of dangerous misinformation (e.g. Ribbans 2020). Meanwhile, the Welsh Government's own five mile travel limit ensured that, if the border was not quite concrete, nor was it quite permeable. In Wales, the epidemiological nation became in distinction and divergence, making an (im)possible border perhaps never so palpably present.

A scholarly 'bordering turn' (Green 2013) has for some time sought to make sense of a chimeric globality in which purportedly fallen borders persist and proliferate: checkpoints re-locate from perimeters to airport arrivals gates and marriage registry offices (Yuval-Davis et al. 2019); dismantled hard borders re-appear in heightened social boundaries (Donnan 2010). Borders, the turn illustrates, are not simply 'phenomena located at the 'edges' of territories but rather 'all over' territories, in innumerable societal practices and discourses' (Paasi 2009: 215). Less concrete coordinates and cartographic lines, borders become through practices and techniques, in the 'process of classifying and ordering space and relations between here and elsewhere' (Green 2013: 350).
If borders run 'all over' (Paasi 2009), nations are intimate spaces. Bordering is often described in a language of intimacy: borders suffuse, saturate, permeate; divide and are transgressed. Along borders, bodies cross, nations rub - and viruses transmit. In an editorial theorising intimacy, Berlant draws attention to the word's bivalent meaning: to intimate is 'to communicate with the sparest of signs and gestures'; to be intimate is relational, 'an aspiration for a narrative about something shared, a story about oneself and others' (1998: 281). Intimacies, Berlant (1998) insists, are at once optimistic fantasies and threatened realities. Such promises and perils are intimately bordered by epidemiological nationalism.

Let me return to the imagined evictions with which I began this essay: fever-dreams of bringing the border into the intimate space of the home rejected by the First Minister whose own national counter-policies had tipped beyond merely intimating distinctly Welsh space. How did epidemiological nationalism move from the borderwork of Welsh Government press conferences, with their sober statistics, through the threatened realities of crossborder contagion, and into open advocacy for policeenforced English expulsion?

Such frictive fears are neither unprecedented nor particularly Welsh. Across the UK, 'hostile environment' policies deploy bordering techniques to 'sensitise people to who carries a British passport and who does not' (Yuval-Davis et al. 2019: 238). Such citizensubjectivities follow state 'securitisation' (Andreas 2003), which frames the national body as continually threatened by the racialised bodies of terrorists, refugees and 'illegal' migrants (El-Enany 2020; Yuval-Davis et al. 2019). As bordering has diffused into daily lives, so the invasive threat has advanced from perimeter to proximity. CCTV cameras, security scans and document checks rehearse transgression's risky immanence. It is not surprising that these already existing bordering techniques emerged in imagining the epidemiologically inscribed nation as a space that could be safely policed from the danger of viral bodies intimated as foreign bodies.

Across Europe, post-war and post-wall identity projects lacquer an intimately scored socio-spatial terrain. Of course, epidemiological nationalism did not emerge everywhere, nor everywhere in the same ways. From the role of German Bundesländer to targeted restrictions on certain cities and regions, many different borders mediated the crisis. 'Following the science' sounded the antiphon to crisis governmentality, but the scale at which to follow became the literal ground for claim and contestation. What 
I have termed epidemiological nationalism asserted the nation's primacy in inscribing unstable borders into spaces of certainty through which safety could prevail and against which contagion could be kept out. Epidemiology enabled territorially intimated and intimately imagined demarcation. Epidemiology also enabled - through national discourses of threat and transgression, security and sentiment - danger to be dis-located by mapping the viral threat onto other nations and into other bodies. Borders arbitrate national intimacies.

\section{Acknowledgements}

This essay derives/departs from my collaboration with Rhys Dafydd Jones, whose support I gratefully acknowledge. An early version was presented at the Johannesburg Institute for Advanced Study webinar 'Borders, Covid-19 and the Global Depression 2.0'. The provocation from editors Simone Dennis and Andrew Dawson gave the piece final shape.

BryonNY Goodwin-HawKINS is an Anthropologist working in interdisciplinary rural and regional studies in the United Kingdom and Central Europe. She is affiliated with the Wales Institute of Social and Economic Research and Data (WISERD), and contributes to the Horizon 2020 projects IMAJINE and ROBUST. E-mail: bgoodwinhawkins@glos.ac.uk

\section{Note}

1. Some $20 \%$ of Wales' population speak Welsh; numbers rise considerably in many rural areas.

\section{References}

Andreas, P. (2003), 'Redrawing the line: Borders and security in the twenty-first century', International Security 28 no.2: 78-111, https://doi.org/10.1162/ 016228803322761973

Barth, F. (1969), Ethnic Groups and Boundaries: The Social Organization of Culture Difference (London: Allen \& Unwin).

Berlant, L. (1998), 'Intimacy: A special issue', Critical Inquiry, 24 no.2: 281-288, https://doi.org/10.1086/ 448875.

Berlant, L. (2008), The Female Complaint: The Unfinished
Business of Sentimentality in American Culture (Durham: Duke University Press).

Dawson, A. \& S. Dennis (2020), 'Disaster nativism: Notes from rural Australia', Social Anthropology, early view, https://doi.org/10.1111/1469-8676.12850.

Donnan, H. (2010), 'Cold War along the Emerald Curtain: rural boundaries in a contested border zone', Social Anthropology, 18 no.3: 253-266, https:// doi.org/10.1111/j.1469-8676.2010.00114.x.

El-Enany, N. (2020), (B)ordering Britain: Law, Race and Empire (Manchester: Manchester University Press).

Goodwin-Hawkins, B. and R. Dafydd Jones (2019), '1997 and 2016: Referenda, Brexit, and (Re-)bordering at the European Periphery', New Global Studies, 13 no. 3: 321-334, https://doi.org/10.1515/ ngs-2019-0031

Green, S. (2013), 'Borders and the relocation of Europe', Annual Review of Anthropology 42: 345-361, https:// doi.org/10.1146/annurev-anthro-092412-155457.

Paasi, A. (2009), 'Bounded spaces in a 'borderless world': border studies, power and the anatomy of territory', Journal of Power 2 no. 2: 213-234, https:// doi.org/10.1080/17540290903064275.

Ribbans, E. (2020), 'In this pandemic, an important lesson: the UK is four nations', The Guardian, 15 May.

Roitman, J. (2013), Anti-Crisis (Durham, N.C.: Duke University Press).

Rumford, C. (2007), ‘Does Europe have cosmopolitan borders?', Globalizations 4 no. 3: 327-339, https:// doi.org/10.1080/14747730701532419.

Saxer, M. and R. Andersson (2019), 'The return of remoteness: insecurity, isolation and connectivity in the new world disorder', Social Anthropology 27 no. 2: 140-155, https://doi.org/10.1111/1469-8676.12652.

Swyngedouw, E. (1997), 'Neither Global Nor Local: 'Glocalization' and the Politics of Scale', in Spaces of Globalization: Reasserting the Power of the Local, (ed.) K. Cox, (New York/London: Guilford/Longman), 137-166.

Taylor, P. (1994), 'The state as container: Territoriality in the modern world-system', Progress in Human Geography, 18 no. 2: 151-162, https://doi.org/10.1177/ 030913259401800202

Trnka, S. (2020), 'Rethinking states of emergency', Social Anthropology, Early view, https://doi.org/10 .1111/1469-8676.12812.

Wilson, T.M. and H. Donnan (2012), 'Borders and border studies' In A Companion to Border Studies, (eds.) T.M. Wilson and H. Donnan, (Chichester: WileyBlackwell), 1-26.

Yuval-Davis, N., G. Wemyss and K. Cassidy (2019), Bordering (Cambridge: Polity Press). 